GA-A15538

UC-77

\title{
MASTER'
}

\section{ANALYSIS OF REACTOR STRATEGIES TO MEET WORLD NUCLEAR ENERGY DEMANDS}

by

D. M. LIGON and R. H. BROGLI

\author{
Prepared under \\ Contract DE-AT03-76ET35300 \\ for the San Francisco Operations Office \\ Department of Energy
}

\section{JULY 1979}




\section{DISCLAIMER}

This report was prepared as an account of work sponsored by an agency of the United States Government. Neither the United States Government nor any agency Thereof, nor any of their employees, makes any warranty, express or implied, or assumes any legal liability or responsibility for the accuracy, completeness, or usefulness of any information, apparatus, product, or process disclosed, or represents that its use would not infringe privately owned rights. Reference herein to any specific commercial product, process, or service by trade name, trademark, manufacturer, or otherwise does not necessarily constitute or imply its endorsement, recommendation, or favoring by the United States Government or any agency thereof. The views and opinions of authors expressed herein do not necessarily state or reflect those of the United States Government or any agency thereof. 


\section{DISCLAIMER}

Portions of this document may be illegible in electronic image products. Images are produced from the best available original document. 


\section{NOTICE}

This report was prepared as an account of work sponsored by the United States Government. Neither the United States nor the United States Department of Energy, nor any of their employees, nor any of their contractors, subcontractors, or their employees, makes any warranty, express or implied, or assumes any legal liability or responsibility for the accuracy, completeness or usefulness of any information, apparatus, product or process disclosed, or represents that its use would not infringe privately owned rights.

Printed in the United States of America

Available from

National Technical Information Service

U.S. Department of Commerce

5285 Port Royal Road

Springfield, Virginia 22161

Price: Printed Copy $\$ 4.50$; Microfiche $\$ 3.00$ 
GA-A15538

UC-77

\title{
ANALYSIS OF REACTOR STRATEGIES TO MEET WORLD NUCLEAR ENERGY DEMANDS
}

\author{
by \\ D. M. LIGON and R. H. BROGLI
}

This report was prepared as an account of work
sponsored by the United States Government. Neither the
United States nor the United States Department of
Energy, nor any of their employees, nor any of their
contractors, subcontractors, or their employees, makes
any warranty, express or implied, or assumes any legal
liability or responsibility for the accuracy, completeness
or usefulness of any information, apparatus, product or
process disclosed, or represents that its use would not
infringe privately owned rights.

Prepared under

Contract DE-AT03-76ET35300

for the San Francisco Operations Office

Department of Energy

GENERAL ATOMIC PROJECT 6400

JULY 1979 
ABSTRACT

A number of reactor deployment strategies for long-term nuclear system development are analyzed from a global perspective in terms of resource utilization and economic benefits. Two time frames are chosen: $1975-2025$ and $1975-2050$.

Uranium demand for various strategies is compared with uranium supply assuming different production capabilities and resource base. The analysis shows that a given reactor deployment strategy could strongly influence the extent of uranium exploration and production.

Power systems cost comparisons are made to identify clearly competitive or non-competitive reactors. The sensitivity of power cost to different uranium price projections and nuclear demands is also examined.

The results indicate that breeders are necessary to support a long-term nuclear power system. Advanced converter-breeder symbiotic systems, particularly those operating on the Th/J-2.3.3 cycle, have clear advantages in terms of resources and economics. 
CONTENTS

$1.0 \quad$ INTRODUCTION................................... 1

1.1 Reactor Strategy Cases...................... 1

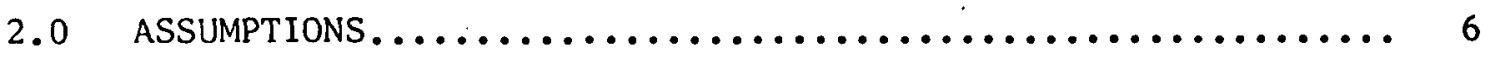

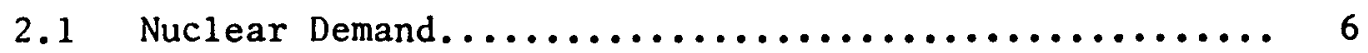

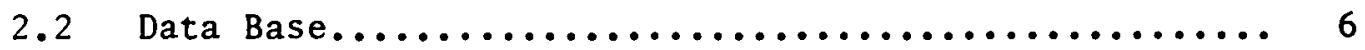

3.0 URANIUM RESOURCES...........................

$4.0 \quad$ RESULTS.................................. 12

4.1 Uranium Utilization...................... 12

4.2 Economics.............................. 19

4.3 Once-Through Strategies.................... 28

4.4 Thermal Recycle Strategies................... 31

4.5 Thermal-Fast Breeder Reactor Symbiosis............ 35

$5.0 \quad$ CONCLUSIONS................................ 40

6.0 REFERENCES................................ 42 
TABLES

1-1. Strategy Scenarios........................... 2

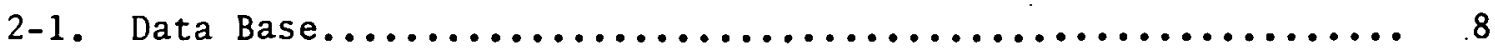

4-1. Cumulative Power Cost for Low Demand/Low Uranium Price Projection................................... 20

4-2 Cumulative Power Cost for High Demand/High Uranium Price Projection.................................. 21

4-3 Cumulative Power Cost for High Demand/Low Uranium Price Projection................................... 22

4-4 Once-Through Strategies, Low Demand/Low Uranium Price........ 29

4-5 Once-Through Strategies, High Demand/High Uranium Price..... 30

4-6 Thermal Recycle Strategies, Low Demand/Low Uranium Price..... 32

4-7 Thermal Recycle Strategies, High Demand/High Uranium Price... 33

4-8 Thermal-Breeder Symbiotic Strategies, Low Demand/ Low Uranium Price............................. 36

4-9 Thermal-Breeder Symbiotic Strategies, High Demand/ High Uranium Price............................ 37 


\section{FIGURES}

$2-1$ Nuclear Demand............................. 7

3-1. Uranium Price Projection $(1978 \$) \ldots \ldots \ldots \ldots \ldots \ldots \ldots \ldots \ldots \ldots$

4-1. Uranium Commitment for Low Nuclear Demand............... 13

4-2 Uranium Commitment for High Nuclear Demand............... 14

4-3 Annual Uranium Requirement vs. Production Capacity.......... 17

4-4 Annual Uranium Requirement vs. Production Capacity.......... 18

4-5 \% Cost Benefit Relative to LWR-STD Once Through, 1975 - 2025.. 23

4-6 \% Cost Benefit Relative to LWR-STD Once Through, 1975 - 2050.. 24

4-7 \% Cost Benefit Relative to LWR-STD Once Through, 1975 - 2025.. 26

4-8 \% Cost Benefit Relative to LWR-STD Once Through, 1975 - 2050 .. 27

4-9 Ratio of Outside to Inside Secured Areas vs. Time.......... 38 


\subsection{INTRODUCTION}

This paper presents a comparison of the uranium utilization and power generation costs of a number of reactor deployment strategies for long-term nuclear system development in the world.

The analyses are based on a global forecast for high and low nuclear demands. (1) Emphasis is given to strategies with advanced converter reactors, such as the HTGR, to demonstrate the performance of these reactors under different conditions. This study also includes systems cost comparisons for the periods 1975 - 2025 and 1975 - 2050 . We recognize the uncertainty of most costs, particularly when applied in a time horizon extending far beyond the year 2000. However, it is worthwhile to see cost trends and to identify the clearly competitive reactor systems or perhaps even more important, the non-competitive ones.

All calculations were performed using the MCFLOW code. To verify our methods (already well proven for U.S. scenarios) for global evaluations, a comparative study between two sample IAEA cases and the corresponding MCFLOW results was performed. It was found that the two methods agree within $2 \%$ for the calculated uranium requirements and plutonium production. (2) Hence, it is expected that while numerical results presented may differ due to different assumptions, these results would be consistent with other international evaluations.

\subsection{REACTOR STRATEGY CASES}

The cases evaluated are listed in Table 1-1. They are grouped into three categories which may represent three possible transition stages for 
TABLE 1-1

STRATEGY SCENARIOS

\begin{tabular}{|cl|c|c|c|}
\hline & Once-Through & Thermal Recycle & Symbiotic System \\
\hline OT 1. & LWR-STD & TR 1. LWR-STD (U/Pu Recycle) & SS 1. LWR-U/FBR/LWR-Pu \\
OT 2. & LWR-STD/LWR-IMP & TR 2. LWR-STD/HWR-SEU/HWR-MEU & SS 2. LWR-U/FBR/HWR-MEU233 \\
OT 3. & LWR-STD/LWR-IMP/HWR & TR 3. LWR-STD/HTGR-MEU & SS 3. LWR-U/FBR/HTGR-MEU233 \\
OT 4. & LWR-STD/LWR-IMP/HTGR-MEU & TR 4. LWR-STD/HTGR-HEU & SS 4. LWR-U/FBR/HTGR-HEU233 \\
\hline
\end{tabular}


world nuclear power development in the future: once-through; once-through followed by thermal recycle; once-through followed by thermal-breeder reactor symbiotic systems.

Five of the cases listed in Table 1-1 (OT4, TR3, TR4, SS3, SS4) emphasize the role of HTGRs operating on either high or medium enriched uranium, with or without recycle or in symbiosis with fast breeder reactors.

The main features of each scenario are:

Once-Through Cycle:

OT 1. LWR-STD Once-Through: Conventional or unimproved LWRs are employed throughout the period.

OT 2. LWR-STD/LWR-IMP, Once-Through: New LWR design leading to $215 \%$ improvement in fuel utilization (due to higher burnup) is retrofitted to existing LWRs beginning in 1990 (100\% by 2005).

OT 3. LWR-STD/LWR-IMP/HWR: This case evaluates the effect of rapid HWR introduction in addition to improvements in LWR design. Beginning in 2001, the number of HWRs built doubles every two years, until the HWR additions reach $100 \%$ of the total nuclear additions. There is' no reprocessing. (Note: The number of HWR operating in the pre-2000 period was derived from Ref. 1).

OT 4. LWR-STD/LWR-IMP/HTGR-MEU: This case evaluates the possible role of the HTGR fueled with denatured $U-233 /$ Th in a oncethrough system. $10 \mathrm{GWe}$ of HTGRs are assumed operating by year 2000. From then on, the number of HTGRs built doubles every two years, until the HTGR additions reach $100 \%$ of the total nuclear additions. 
Thermal Recycle:

TR 1. LWR-U/Pu Recycle: Uranium and plutonium recycle in existing and new LWRs takes place starting in 1991. (100\% by 2005)

TR 2. LWR/HWR-SEU/HWR-MEU: A11 HWR additions after 2000 operate on denatured $U / T h$ fuel with uranium recycle. The same assumptions on LWR installation are used as in Case TR 1. $\mathrm{Pu}$ from HWR is not recycled.

TR 3. LWR/HTGR-MEU: This case also assumes uranium and plutonium recycle in LWRs beginning in 1991 as Case TR 1. Al1 HTGRs are fueled with denatured $U / T h$ with recycle. The same assumptions on HTGR installation are made as in Case OT 4. $\mathrm{Pu}$ from HWR and HTGR is not recycled.

TR 4. LWR/HTGR-HEU: - The same as Case TR 3, except that HTGRs are fueled with high enriched U/Th.

Symbiotic Systems:

SS 1. LWR/FBR: This case is based on U/Pu cycle. Pu from standard LWRs is recycled and used to fuel the fast breeder reactors. The excess $\mathrm{Pu}$ produced by the breeders is burned in LWRs. For high demand: 50 GWe of FBRs operate in 2000. The capacity grows to $150 \mathrm{GWe}$ in 2005. For low demand: $25 \mathrm{GWe}$ of FBRs operate in 2000, 75 GWe in 2005. Thereafter, the FBR market share is limited only by $\mathrm{Pu}$ availability. 
SS 2. LWR/FBR/HWR-MEU233: The breeders installed in this scenario have $U / T h$ blankets to produce U-233. The breeders are themselves self-sufficient in plutonium. HWRs fueled with denatured U-233/Th are introduced after year 2000 and are limited only by U-233 availability.

SS 3. LWR/FBR/HTGR-MEU233: The same conditions as case SS 2. HTGRs fueled with denatured $U-233 / T h$ replace the HWRs.

SS 4. LWR/FBR/HTGR-HEU233: The same as Case SS 3, except HTGRs are fueled with high enriched U-233/Th. 


\subsection{ASSUMPTIONS}

All cases were evaluated for the periods 1975 to 2025 and 1975 to 2050, representing the medium-term and a longer-term time frame, respectively.

\subsection{NUCLEAR DEMAND}

Fig. 2-1 illustrates the demand models used in the analysis. The low case for world nuclear demand reaches $850 \mathrm{GWe}$ in year 2000 and $1800 \mathrm{GWe}$ in 2025. The high case reaches $1200 \mathrm{GWe}$ in year 2000 and $3900 \mathrm{GWe}$ in 2025. The low projection is about 15\% lower than the OECD present trend and the high projection is about $40 \%$ lower than the OECD accelerated growth projection (Ref. 1). Beyond the year 2025, nuclear capacity is assumed to grow linearly at the rate of $30 \mathrm{GWe} / \mathrm{yr}$ and $60 \mathrm{GWe} / \mathrm{yr}$ for the low and high demand respectively.

\subsection{DATA BASE}

Data base for the different reactors used in the analysis are given in Table 2-1. The cost values are consistent with a data base developed by Oak Ridge National Laboratory. 
FIGURE 2-1

NUCLEAR DEMAND

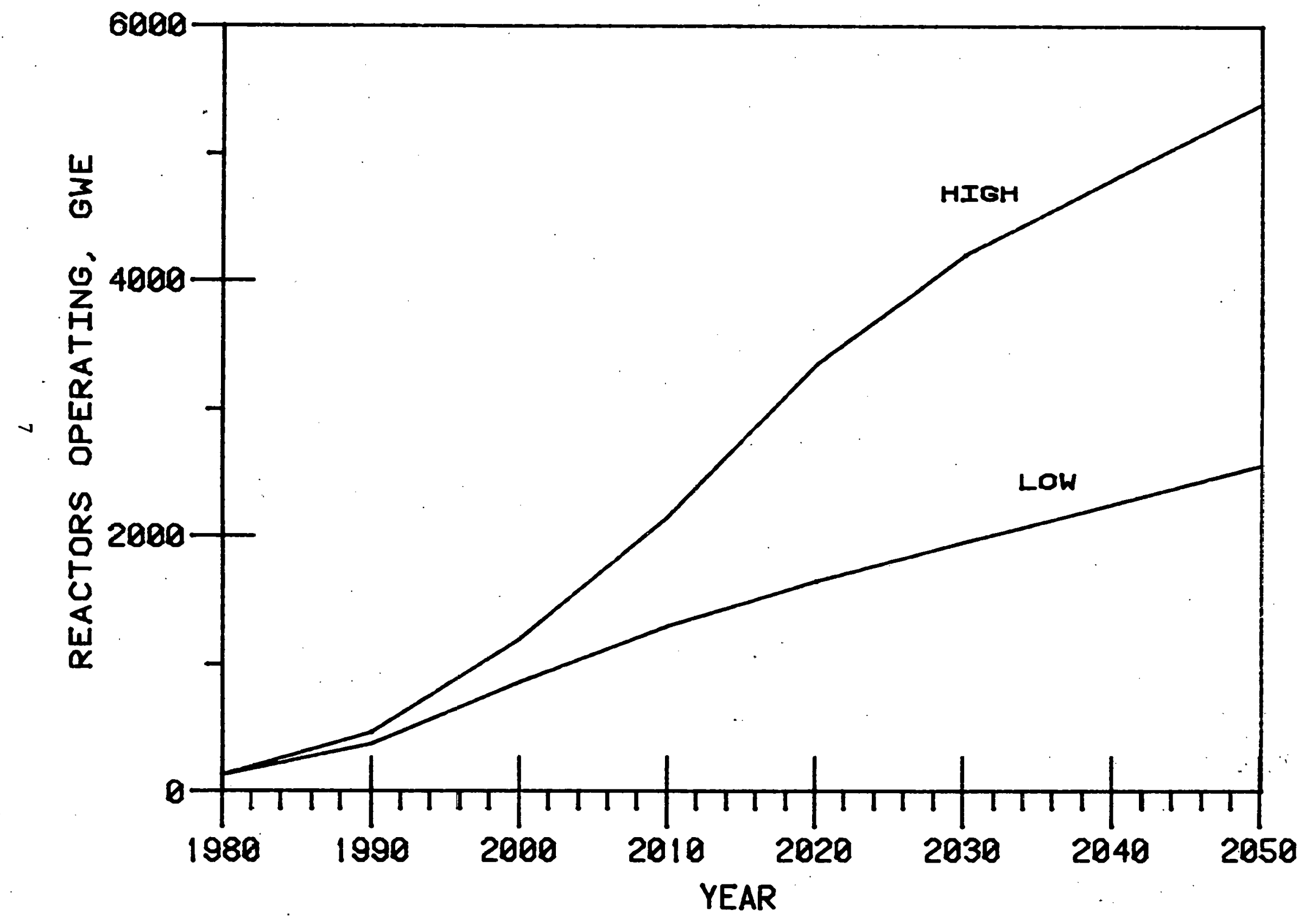


TABLE 2-1

DATA BASE

LWR:

1. LEU/U, Once-Through

2. LEU/U, (U,Pu Stowaway)

3. LEU/U, High Burnup (0/T)

4. $\mathrm{Pu} / \mathrm{U}, \mathrm{Pu}$ Recycle

5. LEU/U, U/Pu Recycle

1. SEU, Once-Through

2. SEU, Stowaway

3. $12 \%$ enr. U-233/Th (U Recycle)

4. $20 \%$ enr. U-235/Th (U Recycle) HTGR:

1. $20 \%$ enr. U-235/Th-0/T

2. $20 \%$ enr. U-235/Th (U Recycle)

3. $93 \%$ enr. U-235/Th (U Recycle)

4. $12 \%$ enr. U-233/Th (U Recycle)

5. $>90 \%$ enr. U-233/Th (U Recycle)

GCFR:

1. $\mathrm{Pu} / \mathrm{U}$ core, $\mathrm{U}$ blankets

2. $\mathrm{Pu} / \mathrm{U}$ core, $\mathrm{U} / \mathrm{Th}$ blankets

\begin{tabular}{|c|c|c|c|c|c|}
\hline \multicolumn{2}{|c|}{$\mathrm{U}_{3}{ }^{0}{ }_{8}$ Requirements } & \multicolumn{2}{|c|}{$\begin{array}{l}\text { Bred Fuel } \\
(\mathrm{kg} / \mathrm{GWe}-\mathrm{yr})\end{array}$} & \multirow{2}{*}{$\begin{array}{l}\begin{array}{c}\text { Capital } \\
\text { Cost* }\end{array} \\
(\$ / K W e)\end{array}$} & $\begin{array}{l}\text { Handling } \\
\text { Cost }\end{array}$ \\
\hline $\begin{array}{l}\text { Inventory } \\
\text { (ST/GWe) }\end{array}$ & $\begin{array}{l}\text { Annual } \\
\text { Reload } \\
\text { (ST/GWe-yr) }\end{array}$ & Available & Added & & $(\$ / \mathrm{kg} \mathrm{HM})$ \\
\hline $\begin{array}{r}385 \\
385 \\
390 \\
92 \\
660\end{array}$ & $\begin{array}{r}170 \\
133 \\
148 \\
31 \\
104\end{array}$ & $\begin{aligned} 165 & (\mathrm{Pu}) \\
150 & (\mathrm{Pu}) \\
113 & (\mathrm{Pu}) \\
0 & \\
0 & \end{aligned}$ & $\begin{array}{r}0 \\
0 \\
0 \\
260(\mathrm{Pu}) \\
0\end{array}$ & $\begin{array}{l}817 \\
817 \\
817 \\
817 \\
817\end{array}$ & $\begin{array}{l}225 \\
485 \\
225 \\
990 \\
625\end{array}$ \\
\hline $\begin{array}{c}234 \\
234 \\
- \\
915\end{array}$ & $\begin{array}{c}100 \\
100 \\
- \\
46\end{array}$ & $\begin{aligned} 140 & (\mathrm{Pu}) \\
140 & (\mathrm{Pu}) \\
23 & (\mathrm{Pu}) \\
11 & (\mathrm{Pu})\end{aligned}$ & $\begin{array}{c}0 \\
0 \\
100(U-233) \\
0\end{array}$ & $\begin{array}{l}1087 \\
1087 \\
1087 \\
1087\end{array}$ & $\begin{array}{l}135 \\
440 \\
885 \\
665\end{array}$ \\
\hline $\begin{array}{r}275 \\
475 \\
700 \\
0 \\
0\end{array}$ & $\begin{array}{r}112 \\
78 \\
46 \\
0 \\
0\end{array}$ & $\begin{aligned} 0 & \\
22 & (\mathrm{Pu}) \\
0 & \\
50 & (\mathrm{Pu}) \\
0 & \end{aligned}$ & $\begin{array}{c}0 \\
0 \\
0 \\
260(\mathrm{U}-233) \\
77(\mathrm{U}-233)\end{array}$ & $\begin{array}{l}840 \\
840 \\
840 \\
840 \\
840\end{array}$ & $\begin{array}{r}920 \\
1260 \\
1150 \\
1510 \\
1150\end{array}$ \\
\hline $\begin{array}{r}\text { Plutonil } \\
(\mathrm{k} \\
\end{array}$ & $\begin{array}{l}\text { Requirements } \\
\text { GWe) }\end{array}$ & & & & $\therefore$ \\
\hline $\begin{array}{l}6100 \\
4900\end{array}$ & $\begin{array}{l}0 \\
0\end{array}$ & $\begin{array}{ll}310 & (\mathrm{Pu}) \\
340 & (\mathrm{U}-233)\end{array}$ & $\begin{array}{l}0 \\
0\end{array}$ & $\begin{array}{l}1010 \\
1010\end{array}$ & $\begin{array}{l}1115 \\
1165\end{array}$ \\
\hline
\end{tabular}




\subsection{URANIUM RESOURCES}

The various opinions on future uranium prices make it difficult to establish a reasonable price projection for uranium. The number of price projections clearly depends on underlying assumptions. The $\mathrm{U}_{3} 0_{8}$ price curves (based on zero inflation) used in this study are illustrated in Figure 3.1 .

The price curves we have developed are based on the latest available resource data from OECD and IAEA reports.' The NEA/IAEA estimates are limited to two cost categories, that is, up to $\$ 30 / 1 \mathrm{~b} \mathrm{U}_{3} 0_{8}(\$ 80 / \mathrm{kg} \mathrm{U})$ and $\$ 30-50 / 1 \mathrm{~b} \mathrm{U}_{3}{ }_{8}(\$ 80-130 / \mathrm{kg} \mathrm{U})$. An estimated 4.1 million short tons $\mathrm{U}_{3} 0_{8}$ ( 3.2 million tonnes $U$ ) in the Reasonably Assured Resources (RAR) and Estimated Additional Resources (EAR) categories are assumed to be available at less than $\$ 30 / 1 b \mathrm{U}_{3} 0_{8}$ forward cost. An additional 1.5 million short tons $\mathrm{U}_{3} \mathrm{O}_{8}$ ( 1.13 million tonnes $U$ ) are available at a cost between $\$ 30$ $50 / 1 \mathrm{~b} \mathrm{U}_{3} \mathrm{O}^{\circ}$

A recent OECD report (Ref. 2) on world uranium potential (WOCA region) suggests that the speculative uranium resource estimates falling into the cost ranges below $\$ 50 / 1 \mathrm{~b} \mathrm{U}_{3}{ }^{0} 8$ range from 8.6 - 19.2 million short tons $\mathrm{U}_{3} 0_{8}(6.6-14.8 \mathrm{million}$ tonnes $\mathrm{U})$. This amount indicates undiscovered resources and there is no guarantee that they can be made available at the current estimated cost ranges or in the necessary time period.

This limited data was used to develop the $\mathrm{U}_{3} 0_{8}$ price curves shown in Fig. 3-1. $\mathrm{U}_{3} \mathrm{O}_{8}$ price was assumed to be twice the production cost. For the high cost range, we assumed that only the $\mathrm{U}_{3} 0_{8}$ in the reserves and estimated resources categories would be available at a market price of $\$ 100 / 1 \mathrm{~b} \mathrm{U}_{3} 0_{8}$. The price beyond this amount $\left(\sim 6.0 \mathrm{MST} \mathrm{U}_{3} \mathrm{O}_{8}\right)$ was assumed 
FIGURE 3-1

URANIUM PRICE PROJECTION (1978 \$)

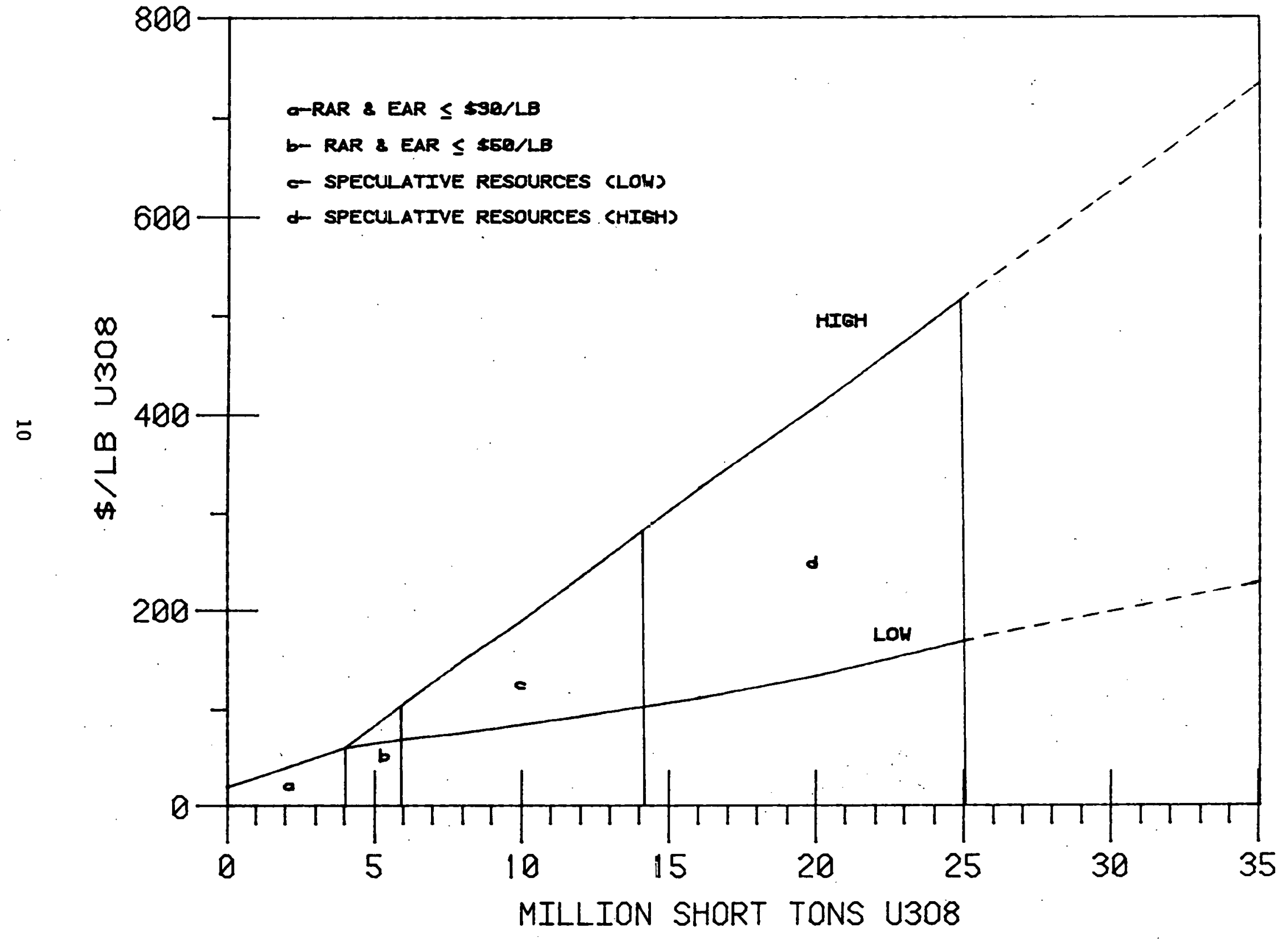


to increase linearly to around $\$ 420 / 1 \mathrm{~b} \mathrm{U}_{3} 0_{8}$ for a cumulative demand of 20 million short tons. The lower price range, on the other hand, assumes that 8 million ST $\mathrm{U}_{3}{ }_{8}$ of highly speculative resources would be available at $\$ 100 / 1 \mathrm{~b}$, in addition to the 6 million ST of reserves and estimated resources. Thus, the following price ranges were established.

$\begin{array}{crr}\text { Cum. } \mathrm{U}_{3}{ }_{8}\left(10^{6} \mathrm{ST}\right) & \mathrm{U}_{3}{ }_{8} \text { Price } & \text { (2xForward Cost) } \\ 4.1 & \underline{\text { High }} & \text { Low } \\ 6.0 & 60 & 60 \\ 14.0 & 100 & 70 \\ 20.0 & 275 & 100 \\ & 420 & 140\end{array}$

This price structure seems to agree reasonably well with the corresponding U.S. price and supply projections. 


\subsection{RESULTS}

The results of the strategy evaluations are presented in the following sections. Section 4.1 gives an overall comparison of the uranium utilization and Section 4.2 discusses the economics of once-through, thermal recycle and thermal-breeder symbiotic strategies. Sections 4.3 to 4.6 discuss in detail each case analyzed.

\subsection{URANIUM UTILIZATION}

In the light of the present concern regarding the adequacy of world uranium supply to meet nuclear demand, the uranium commitment or 30-year lifetime requirement of reactors in operation is useful information. The extent of uranium commitment for a particular strategy could provide the necessary stimulation for uranium exploration and production. In Figs. 4-1 and 4-2, the uranium commitments for representative scenarios (for low and high demand, respectively) are compared with various types of uranium resources based on latest OECD-NEA estimates. (4) A more detailed intercomparison of uranium consumption for each case within a strategy category is discussed in Sections 4.3 to 4.5 .

For a low demand model (Fig. 4-1) the known reserves of about 2.2 million short tons $\mathrm{U}_{3} \mathrm{O}_{8}$ are committed by 1990 . The additional resources of about 3.8 million short tons $\mathrm{U}_{3}{ }_{0}{ }_{8}$ would be committed by year 2005 for an LWR Once-through system. Incorporation of design improvements in the LWR which would reduce fuel consumption by about $12 \%$ would only extend the use of these resources by $2-3$ years. These resources would be committed by i2010 in an LWR recycle system. The introduction of advanced converters (i.e., HTGR or HWR) would extend this to 2015. Given an additional 8.5 million short tons $\mathrm{U}_{3}{ }_{0}$ (speculative resources, low estimate) these resources 
FIGURE 4-1

URANIUM COMMITMENT FOR LOW NUCLEAR DEMAND

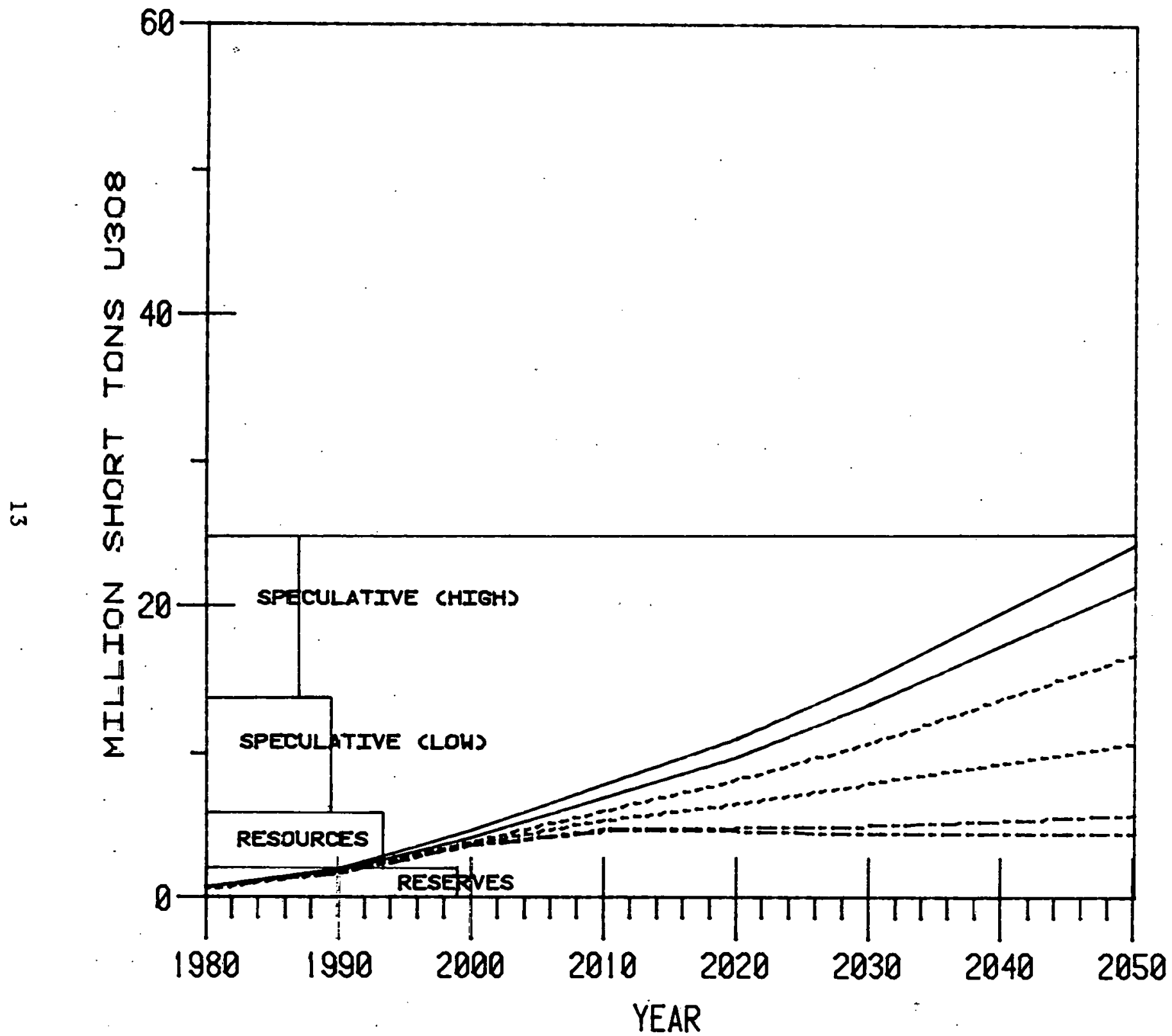

OT 1. LHR-STD

OT2. LWR-STD/LWR-IMP

TR1 . LWR-STD

TR4. LWR-STD/HTER-HEU

SSI. LWR/FBRCPUS

SS4: LWR/FBR/HTGR-HEU293 
FIGURE $\quad 4-2$

URANIUM COMMITMENT FOR HIGH NUCLEAR DEMAND

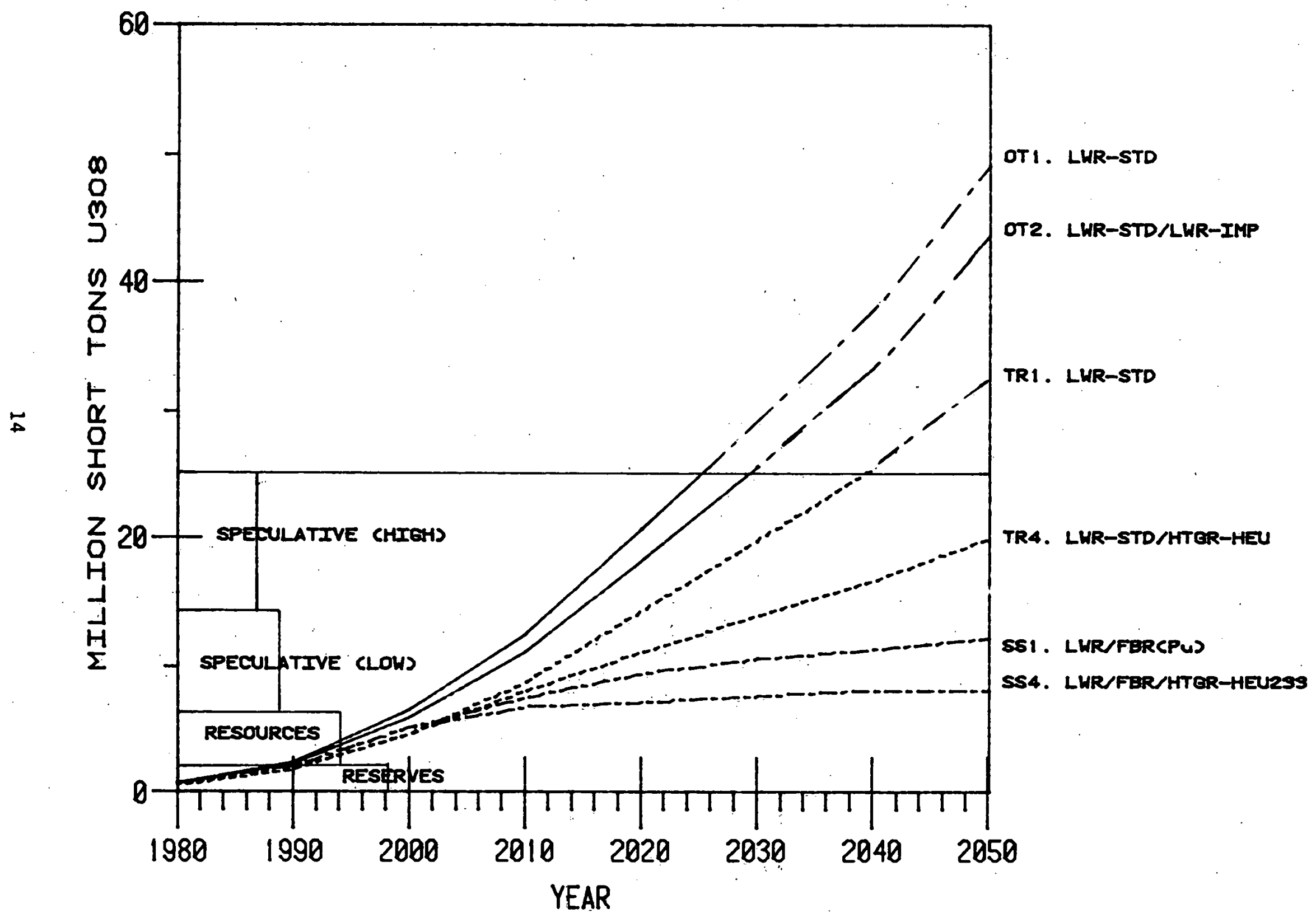


would be committed by 2030 for the standard LWR-only case. However, it is doubtful that these speculative resources would be available during this time period. A recent DOE study estimates that only about 2.5 to 4.0 million tonnes uranium $\left(3.25-5.20\right.$ million short tons $\left.U_{3} 0_{8}\right)$ may be recovered by year 2025.

For a higher power demand (Fig. 4-2) the LWR once-through curve shows a steeper slope. A significant increase in uranium resources is necessary to maintain the system. Uranium commitment up to 2050 is more than 40 million short tons for a once-through system with improved LWR fuel.

Thus, while once-through systems would certainly require an accelerated speculative resource development, it is difficult, if not impossible that demands would be met in the necessary time period.

For the breeder cases the estimated resources of $\sim 6.0 \mathrm{MST} \mathrm{U}_{3} \mathrm{O}_{8}$ (Reserves and Resources) would be sufficient to maintain the low growth demand beyond the year 2050. The symbiotic system involving the U-233 exchange between FBRs and ACRs would require about 4 million short tons $\mathrm{U}_{3} 0_{8}$ for low demand and about 8 million short tons for high demand. Eventually, when equilibrium is achieved, the system will be self-sufficient in fuel. On the other hand, the LWR/FBR system operating on plutonium cycle, does not lead to a levelling off of uranium commitment because the Pu-fueled LWRs which are installed to burn the excess $\mathrm{Pu}$ produced by the breeders, have an annual requirement of $\sim 30 \mathrm{ST} \mathrm{U}_{3} \mathrm{O}_{8} / \mathrm{GWe}-\mathrm{yr}$.

The development of uranium resources to meet uranium demands of symbiotic systems, which are considerably less than once-through or thermal recycle systems, is largely dependent on the rate of breeder development. Rapid FBR development would delay, while slow FBR developmwnt would accelerate the speculative resouree development. 
In addition to the availability of uranium resources, we should also consider the world uranium production capability. OECD estimates that the global annual production by 1990 would be about 143,000 short tons $\mathrm{U}_{3} \mathrm{O}_{8}{ }^{\text {(5) }}$ Production from known resources for all countries is expected to peak during the 1990 - 2000 period with production declining during the next quarter century. However, a greater demand for uranium could stimulate production from new discoveries. Considering a very optimistic climate, DOE estimates that production capacity by 2025 could be as much as three times the 1990 level. It is very likely that uranium supply in any year could fall within the range of these two extremes. Thus; a production capacity of about 170,000 short tons by 2025 could be a more reasonable estimate. It is important that one recognizes the big uncertainty inherent in estimating just how high a production rate could be sustained.

Figure 4-3 compares the uranium requirements of representative scenarios with the estimated annual production capacity range for a low nuclear growth. Uranium requirements of all systems including once-through systems fall below the upper range of the projected annual production capacity. Should production capacity fall in the middle range $(\sim 170,000$ ST $U_{3} 0_{8}$ by 2025), the LWR once through strategies would not make it by 2015. By the year 2025, only the symbiotic systems and the thermal recycle with HTGR-HEU system would have annual needs below the mid-range production capacity.

Figure 4-4 shows the same comparison for a high nuclear growth. For the high demand, the maximum production capacity by 2025 falls short of the annual requirements of once-through systems. Even a symbiotic system with LWRs and FBRs operating on Pu cycle would not make it by 2025, if production capacity falls in the mid-range of the projected estimate $\left(170,000 \mathrm{ST}_{3}{ }_{8}\right.$ in 2025). It is safe to assume then that the FBR/HTGR-HEU233 system with an annual requirement of $140,000 \mathrm{ST} \mathrm{U}_{3} \mathrm{O}_{8}$ by 2025 is the least susceptible to uncertainties in uranium production capacity. 
FIGURE 4-3

ANNUAL URANIUM REQUIREMENT VS. PRODUCTION CAPACITY

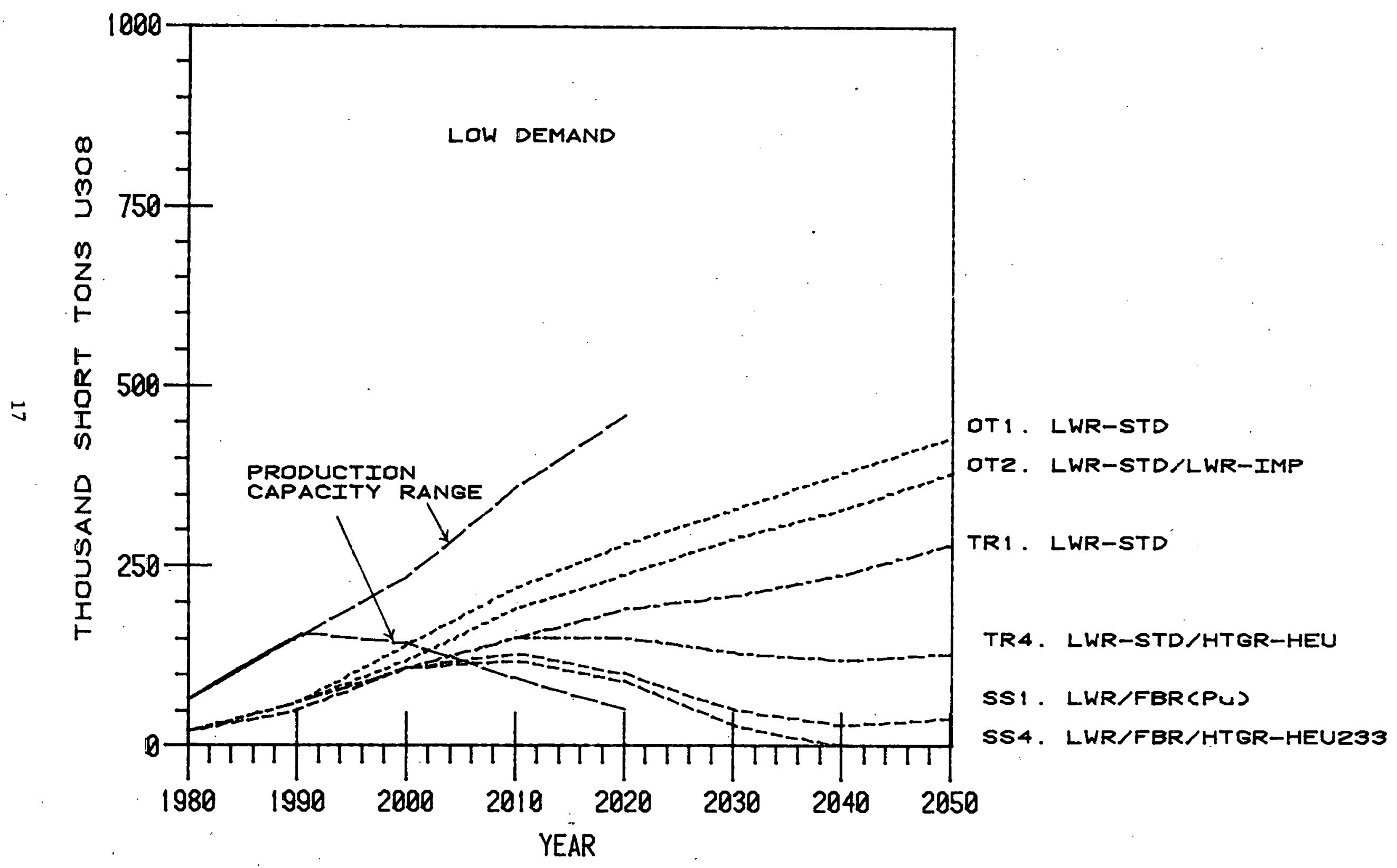


FIGURE 4-4

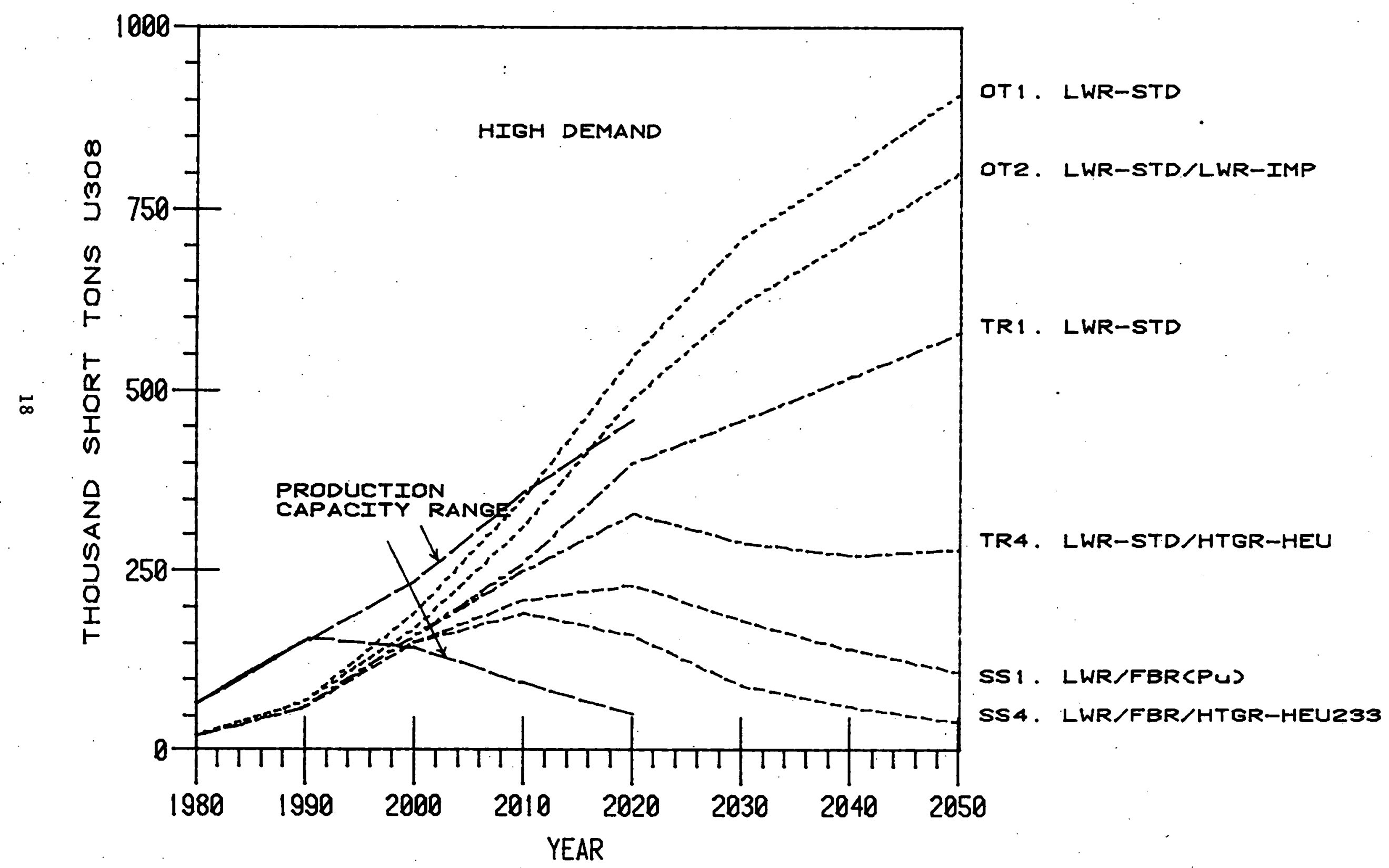




\subsection{ECONOMICS}

Tables 4-1, 4-2 and 4-3 give the discounted power cost for the. different strategies for a low demand/low uranium price, a high demand/ high uranium price and a high demand/low uranium price projection, respectively. Benefits (or penalties) relative to a standard LWR are illustrated schematically in Fig. 4-5 for the low demand/low uranium and high demand/high uranium price projection for the period 1975 to 2025 and in Fig. 4-6 for the period 1975 - 2050.

The trend of present nuclear planning strongly indicates that LWRs will continue to dominate nuclear power scenarios until the end of the century. Advanced reactor concepts will most likely be deployed by year 2000 or even later. The decision made for the post-2000 period of whether to continue using LWRs or to employ ACRs and FBRs, will be highly influenced by the economics. Thus, for long-term power cost comparison between LWRonly systems and alternate reactor strategies, discounting to year 2000 (setting aside all costs incurred before the year 2000) is useful, in order to provide the decision makers with results indicative of the future economic situation depending on what option is chosen.

The results indicate that up to the year 2025, once-through systems with improved LWRs and/or HTGRs, in a low demand/low uranium price situation, have lower power costs than thermal recycle or breeder systems. This suggests that the $\mathrm{U}_{3}{ }_{8}$ price has not yet risen to a point where the fue 1 cost savings due to the use of recycled fuel in more efficient advanced reactors could compensate for the higher capital and handling costs associated with these reactors. The benefits from the use of FBRs and/or ACRs hecome apparent with high demand/high uranium price projection, indicating that costs are highly sensitive to nuclear demand and uranium price assumptions. For the thermal recycle system, the power cost resulting from the use of denatured U/Th fuel in the HTGR is lower than with high enriched $U / T h$. In this time frame, 1975 - 2025, there is very little 
TABLE 4-1

CUMULATIVE POWER COST FOR LOW DEMAND/LOW URANIUM PRICE PROJECTION

(Discounted to year 2000 at $4.5 \%$ )

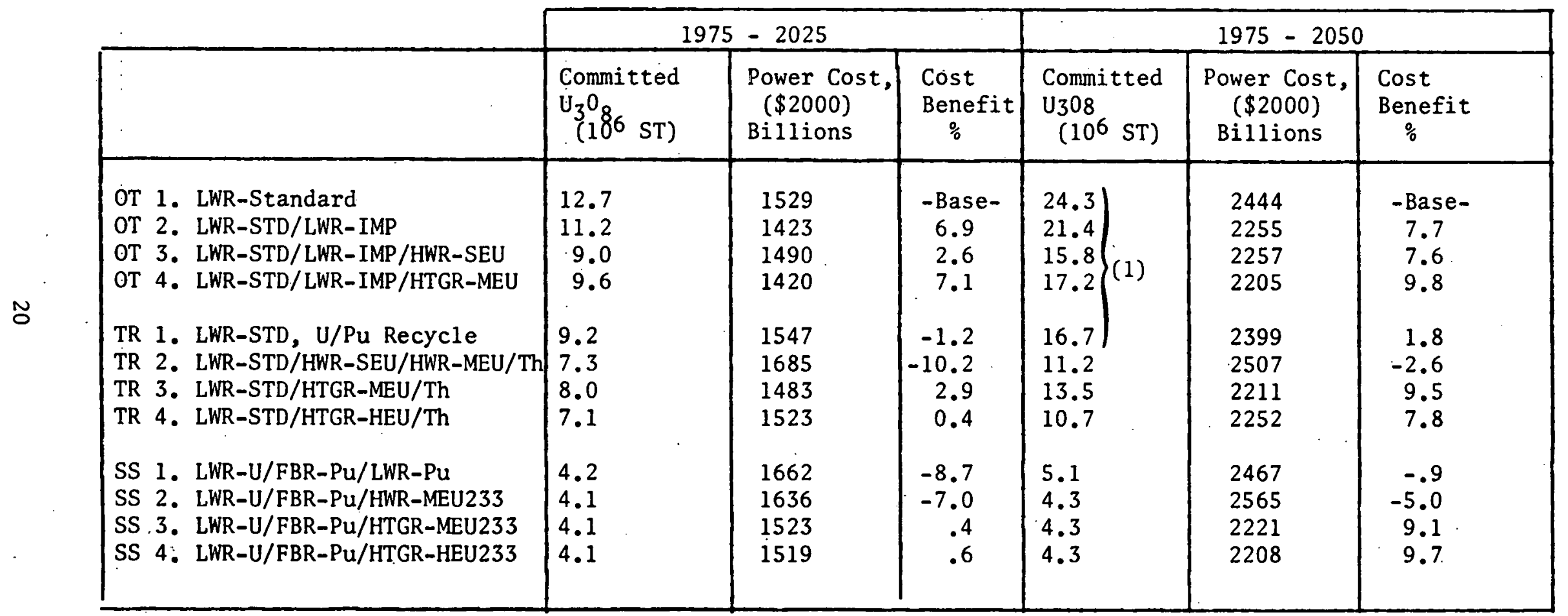

* (1). Doubtful: U > low speculative resources 
TABLE 4-2

CUMULATIVE POWEF. COST FOR HIGH DEMAND/HIGH URANIUM PRICE PROJECTION

(Discounted to Year 2000 at $4.5 \%$ )

\begin{tabular}{|c|c|c|c|c|c|c|}
\hline & \multicolumn{3}{|c|}{$1975-2025$} & \multicolumn{3}{|c|}{$1975-2050$} \\
\hline & $\begin{array}{l}\text { Committed } \\
\mathrm{U}_{308} \\
\left(10^{6} \mathrm{ST}\right)\end{array}$ & $\begin{array}{l}\text { Power Cost } \\
(\$ 2000) \\
\text { Billions }\end{array}$ & $\begin{array}{l}\text { Cost } \\
\text { Benefit } \\
\frac{\%}{\%}\end{array}$ & $\begin{array}{l}\text { Committed } \\
\text { U308 } \\
\text { (106 ST) }\end{array}$ & $\begin{array}{l}\text { Power Cost, } \\
(\$ 2000) \\
\text { Billions }\end{array}$ & $\begin{array}{l}\text { Cost } \\
\text { Benefit, } \\
\quad \%\end{array}$ \\
\hline $\begin{array}{ll}\text { OT } & \text { 1. LWR-Standard } \\
\text { OT } & \text { 2. LWR-STL/LWR-IMP } \\
\text { OT } & \text { 3. LWR-STLI/LWR-IMP/HWR-SEU } \\
\text { OT } & \text { 4. LWR-STLILWR-IMP/HTGR-MEU }\end{array}$ & $\left.\begin{array}{l}25.3 \\
22.3 \\
17.4 \\
19.0\end{array}\right)(1)$ & $\begin{array}{l}3920 \\
3497 \\
3423 \\
3346\end{array}$ & $\begin{array}{c}- \text { Base- } \\
10.8 \\
12.7 \\
14.6\end{array}$ & $\left.\begin{array}{l}49.1 \\
43.6 \\
31.2 \\
34.6\end{array}\right\}$ & $\begin{array}{l}8689 \\
7383 \\
6060 \\
6327\end{array}$ & $\begin{array}{c}- \text { Base- } \\
15.0 \\
30.3 \\
27.2\end{array}$ \\
\hline $\begin{array}{l}\text { TR 1. LWR-STE, U/Pu Recycle } \\
\text { TR 2. LWR-STE/HWR-SEU/HWR-MEU/Th } \\
\text { TR 3. LWR-STE/HTGR-MEU/Th } \\
\text { TR } \\
\text { 4. LWR-STE/HTGR-HEU/Th }\end{array}$ & $\begin{array}{l}17.4 \\
12.8 \\
14.7 \\
12.7\end{array}$ & $\begin{array}{l}3503 \\
3755 \\
3281 \\
3354\end{array}$ & $\begin{array}{r}10.6 \\
4.2 \\
16.3 \\
14.5\end{array}$ & $\left.\begin{array}{l}32.5 \\
20.7 \\
25.8 \\
20.0\end{array}\right)(1)$ & $\begin{array}{l}6466 \\
5914 \\
5488 \\
5298\end{array}$ & $\begin{array}{l}25.6 \\
31.9 \\
36.8 \\
39.1\end{array}$ \\
\hline $\begin{array}{lll}\text { SS } & \text { 1. LWR-U/FBR-Pu/LWR-Pu } \\
\text { SS } & \text { 2. LWR-U/FBR-Pu/HWR-MEU233 } \\
\text { SS } & \text { 3. LWR-U/FBR-Pu/HTGR-MEU233 } \\
\text { SS } & \text { 4. SWR-U/FBR-Pu/HTGR-HEU233 }\end{array}$ & $\begin{array}{r}12.6 \\
11.3 \\
9.7 \\
9.5\end{array}$ & $\begin{array}{l}3428 \\
3383 \\
3093 \\
3082\end{array}$ & $\begin{array}{l}12.6 \\
13.7 \\
21.1 \\
21.4\end{array}$ & $\begin{array}{l}15.0 \\
12.1 \\
11.9 \\
10.2\end{array}$ & $\begin{array}{l}5217 \\
5342 \\
4622 \\
4544\end{array}$ & $\begin{array}{l}40.0 \\
38.5 \\
46.8 \\
47.7\end{array}$ \\
\hline
\end{tabular}

(1) Doubtful: U > low speculative resources

(2) Not feasible: $U>$ high speculative resources 
TABLE 4-3

CUMULATIVE POWER COST FOR HIGH DEMAND/LOW URANIUM PRICE PROJECTION

(Discounted to Year 2000 at $4.5 \%$ )

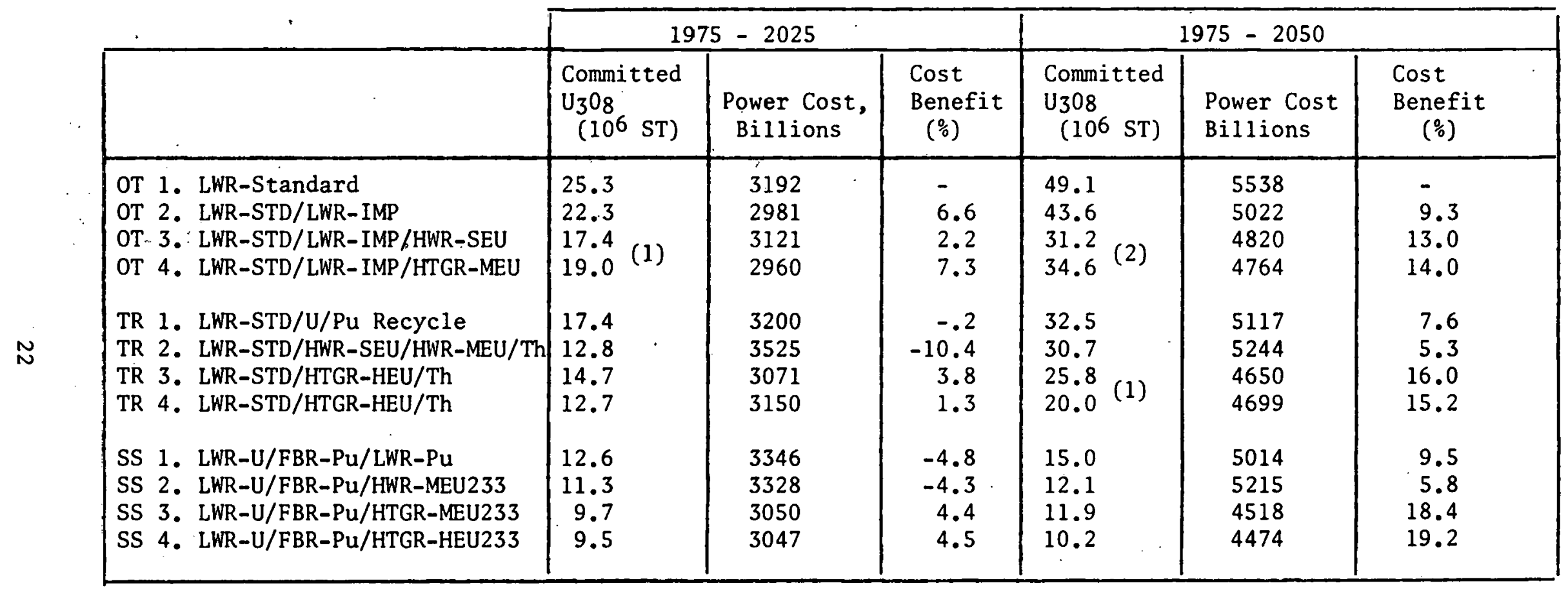

(1) Doubtful: U > low speculative resources

(2) Not feasible: $U>$ high speculative resources 


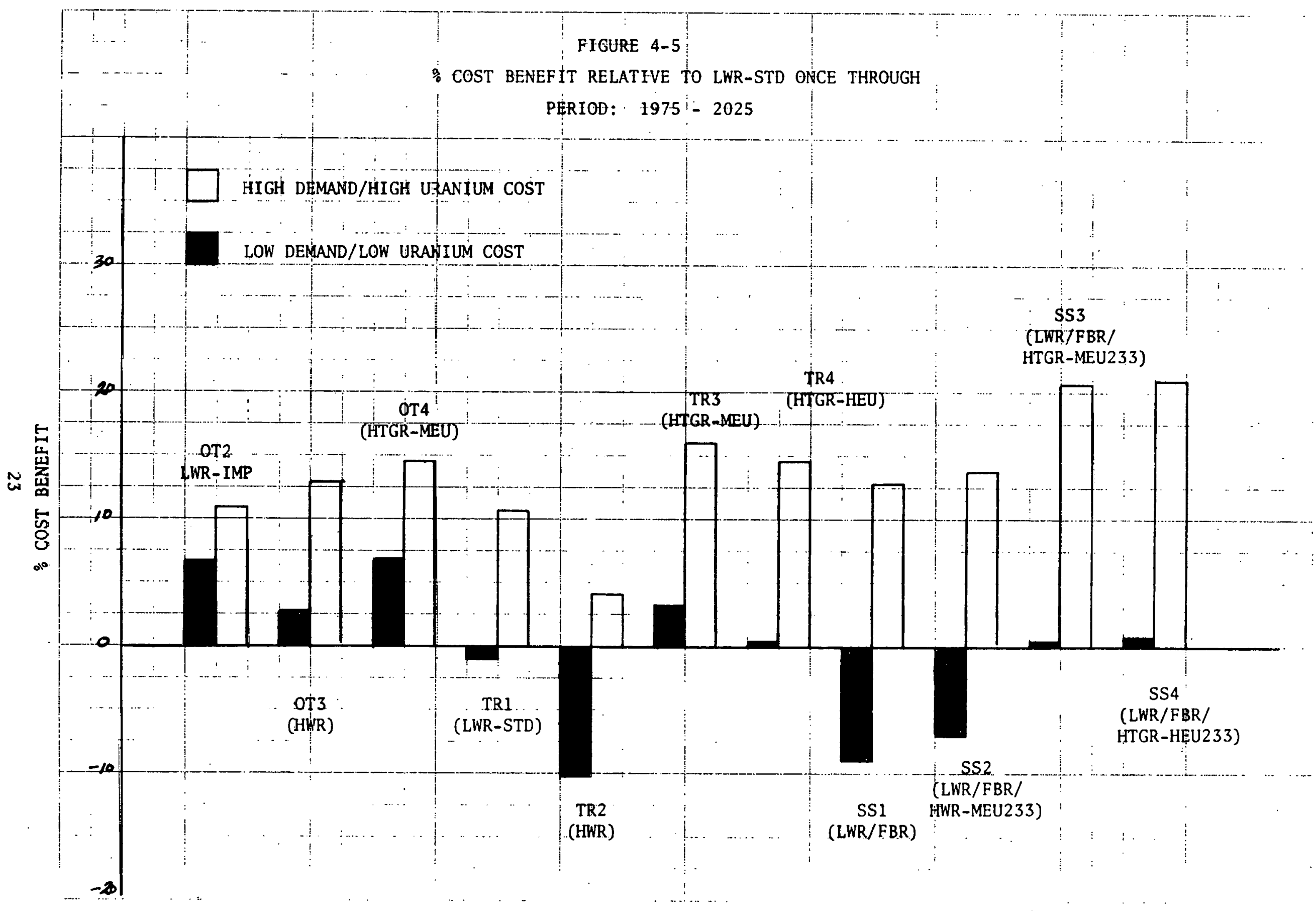




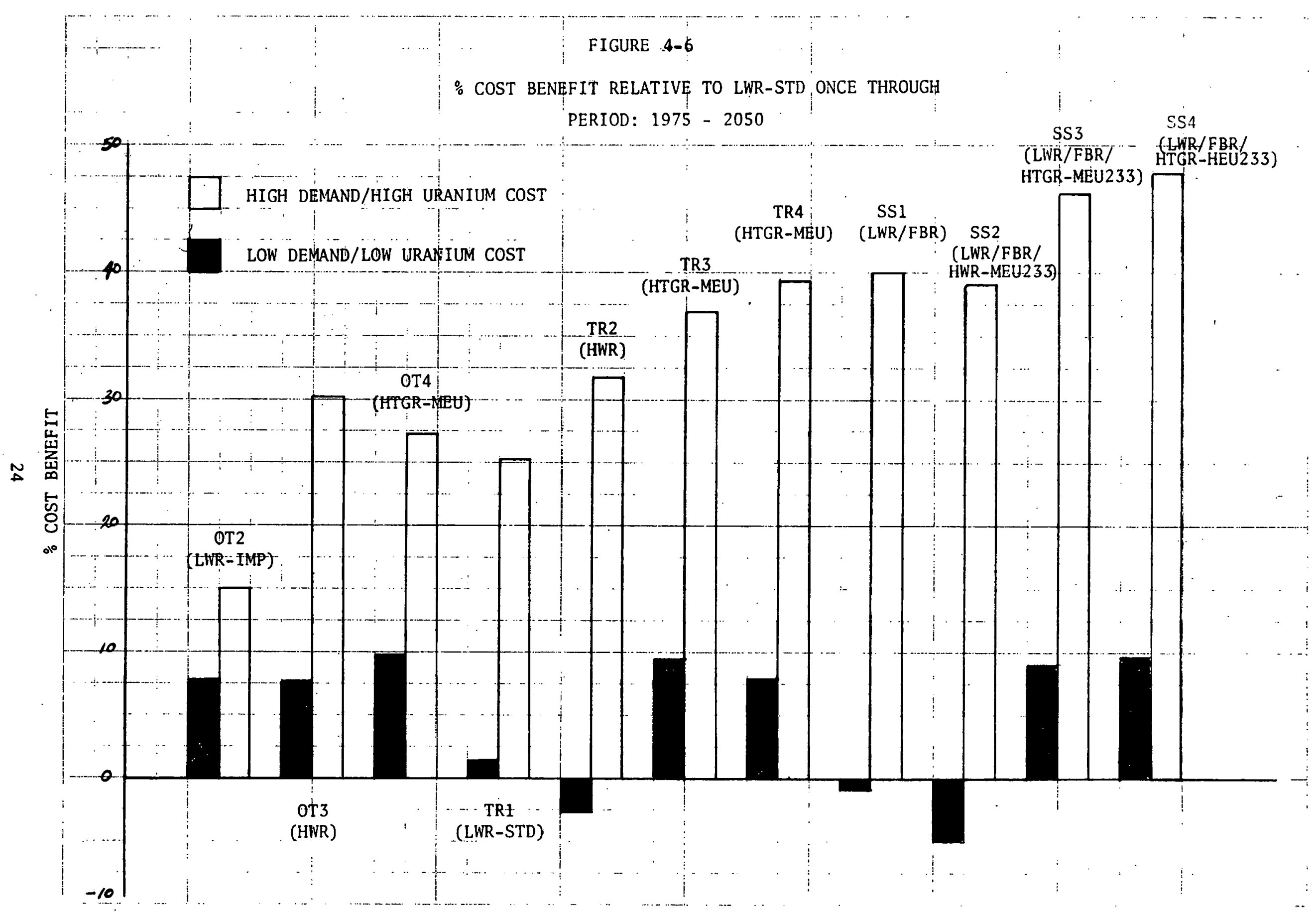


difference in the amount of uranium consumed in each system, even though the HTGR-HEU is more fuel efficient. This is largely due to the higher inventory requirement of the HTGR-HEU (700 ST $\mathrm{U}_{3}{ }_{8}{ }_{8} / \mathrm{GWe}$ vs. $475 \mathrm{ST}_{3} \mathrm{U}_{8} /$ GWe for HTGR-MEU). Therefore, the higher metal loading and enrichment requirements of the HTGR-HEU contribute to the increased cost over the period $1975-2025$.

When the analysis is extended to 2050, significant benefits are derived from thermal-breeder symbiosis or thermal recycle with HTGRs. For a low demand/low uranium price projection, the benefits from these systems are of the same magnitude as the improved LWR once-through system. However, the thermal recycle and symbiotic strategies have an important unquantified benefit because they are less susceptible to uncertainties in uranium supplies which could lead to highly unstable uranium market price.

A11 cases with HTGR show higher benefits compared to other reactor types. On the other hand, the HWRs which are also highly fuel efficient reactors, have high capital and handling costs, making them less preferred over the HTGRs or FBRs.

Figures 4-7 and 4-8 show the sensitivity of the cost benefits to uranium price for the high growth projection for the periods 1975 to 2025 and 1975 to 2050 , respectively. While it is possible that a high demand situation could lead to higher ore prices, particularly when resources are low, it is also possible that high demand could accelerate the rate of discoveries and production leading to lower uranium price. Should this happen, we find that the benefits from thermal recycle and thermal-breeder symbiotic systems are drastically reduced. However, by the year 2050, benefits particularly from FBR/ACR (on U-233) systems are still meaningful. 


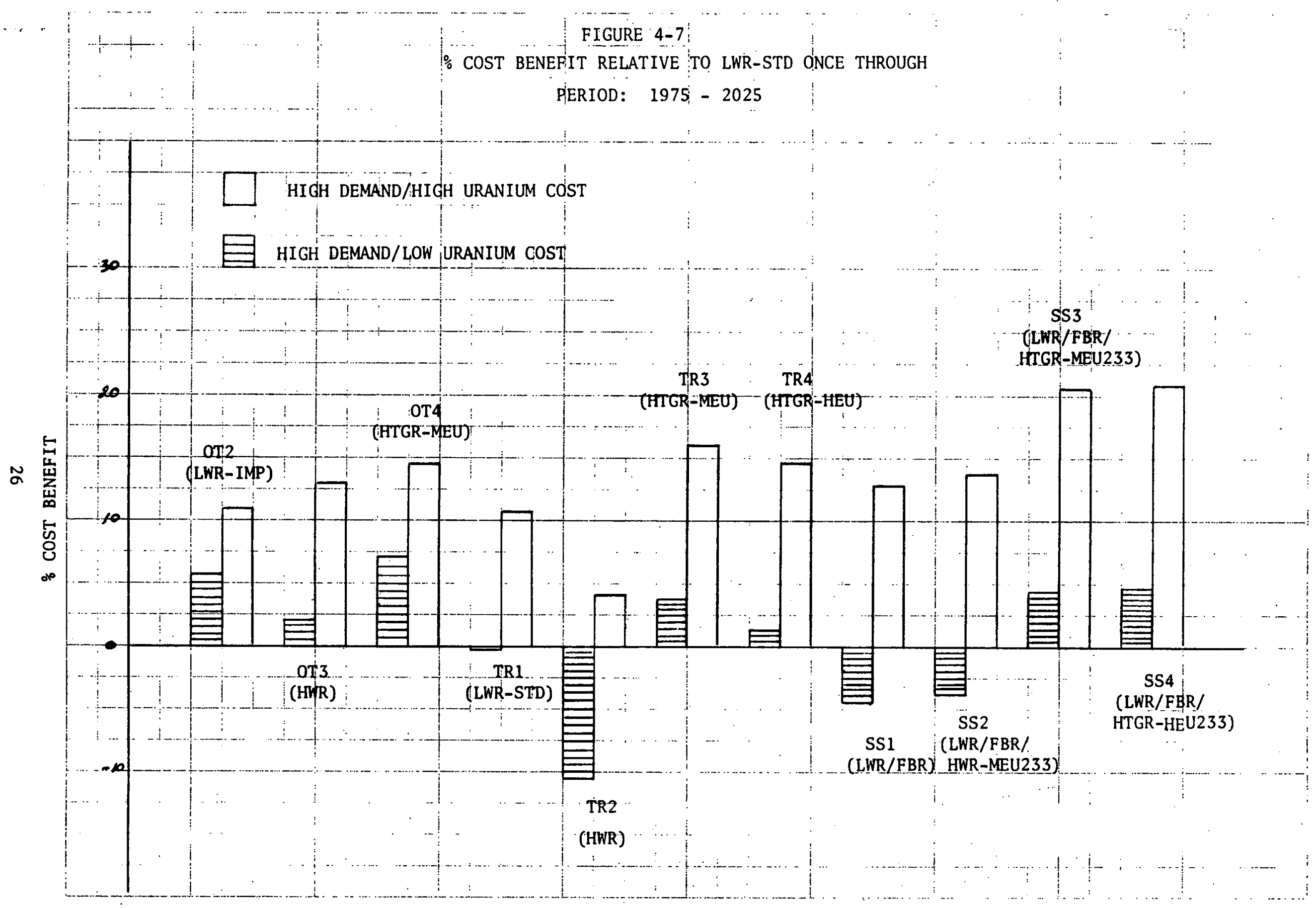




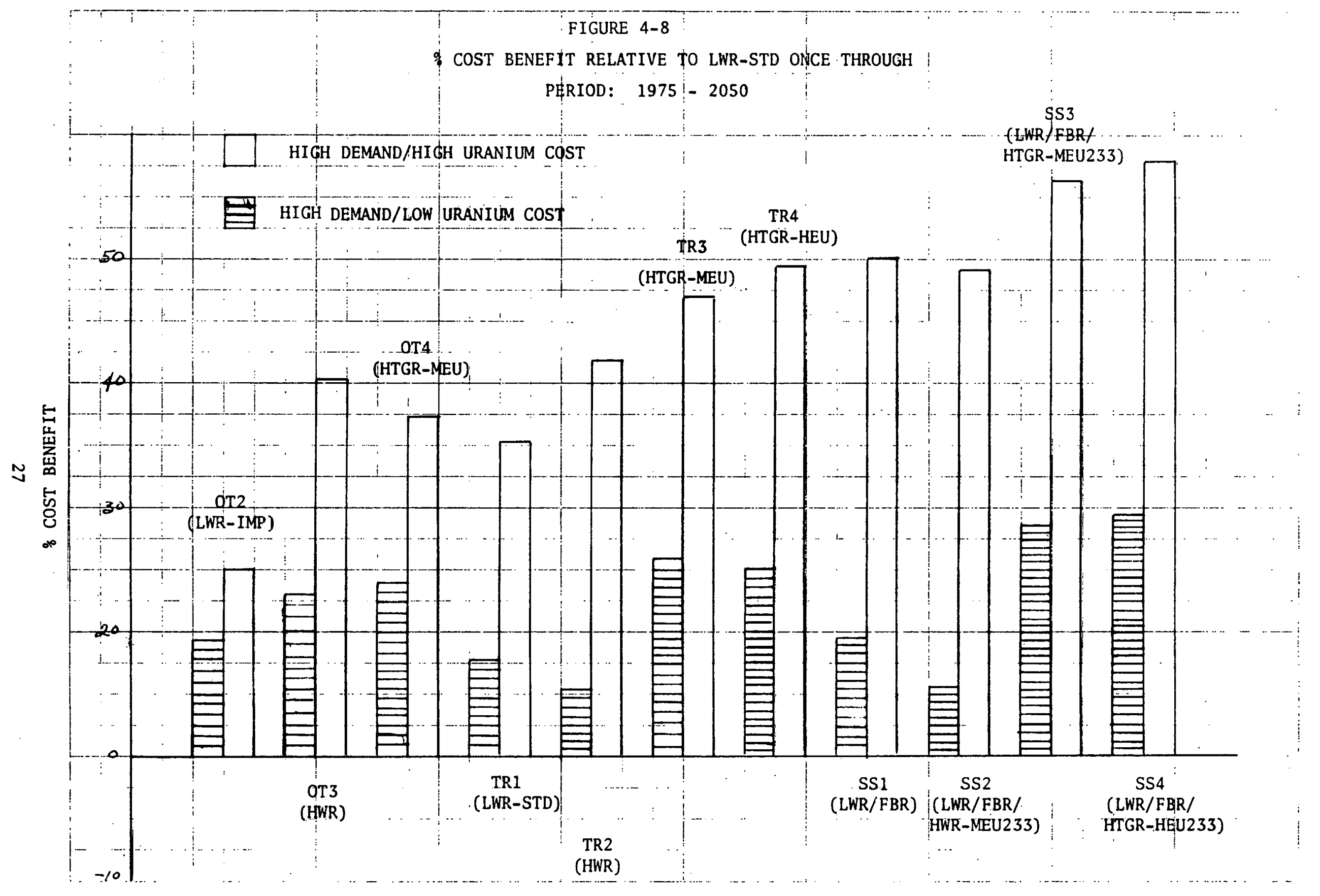


For the long-term, the ACR/FBR symbiosis with U-233/Th fuel looks economically favorable, particularly in a high demand/high uranium price situation. These benefits are maximized with rapid deployment of fast breeder and advanced converter reactors. Furthermore, it is necessary that LWR spent fuel should not be largely committed to thermal recycle. Otherwise, this will constrain the initial rate for breeder deployment and would permit a rise in the market pressures on uranium supplies.

\subsection{ONCE-THROUGH STRATEGIES}

Table 4-4 gives the uranium used through 2025 and 2050, and the fuel, capital and handling costs for once-through strategies for low demand/low uranium price. Table 4-5 gives the same information for the high demand/ high uranium price projection.

In this study, the $12 \%$ improvement in $U_{3} 0_{8}$ utilization in the LWR is made possible through an increase in LWR fuel discharge exposure, from the current reference design of $33,000 \mathrm{MWD} / \mathrm{MT}$ to $50,000 \mathrm{MWD} / \mathrm{MT}$. This results in a reactor residence time of five years, versus three years for the standard LWR.

Until 2025, the total $\mathrm{U}_{3} 0_{8}$ used for a system with high burnup LWR fuel is 1.5 million short tons less than one with standard LWRs only for high demand projection. The saving more than doubles by year 2050. The lower power cost of the improved LWR system is attributed not only to the saving in fuel but also to reduced handling cost. The lower heavy metal loading and the fact that the fuel stays in the core for a longer period than the standard LWR fuel reduce handling cost by about $34 \%$.

The once-through system with HWRs fueled with slightly enriched uranium uses about $9 \%$ less $\mathrm{U}_{3} \mathrm{O}_{8}$ than the HTGR-MEU system. This fuel saving becomes highly important as the price of $\mathrm{U}_{3} \mathrm{O}_{8}$ escalates. Thus we find that in a low demand/low uranium price situation, the high capital and handling 
TABLE $4-4$

ONCE-THROUGH STRATEGIES*

LOW DEMAND/LOW URANIUM PRICE

\begin{tabular}{|c|c|c|c|c|c|c|}
\hline \multirow{3}{*}{\multicolumn{2}{|c|}{ OT 1. LWR-STD }} & \multirow{2}{*}{$\begin{array}{l}\mathrm{U}_{3}{ }^{0}{ }_{8} \text { Used Up } \\
\text { to } 2025 \text { (2050) } \\
\left(10^{6} \mathrm{sT}\right)\end{array}$} & \multicolumn{4}{|c|}{$\begin{array}{c}\text { Power Generation Cost to } 2025(2050) \text {, Billions } \$ \\
\text { (Discounted to Year } 2000 \text { at } 4.5 \% \text { ) }\end{array}$} \\
\hline & & & Fue1 & Capital & Handling & Total \\
\hline & & $7.9(17.3)$ & $668(1150)$ & $737(1103)$ & 124 (191) & $1529(2444)$ \\
\hline OT 2 & LWR-STD/LWR-IMP & $7.0(15.3)$ & $605(1027)$ & $737(1103)$ & $81(125)$ & $1423(2255)$ \\
\hline OT 3 & LWR-STD/LWR-IMP/HWR-SEU & $6.1(11.7)$ & $462(677)$ & $930(1416)$ & $98(164)$ & $1490(2257)$ \\
\hline OT 4 & LWR-STD/LWR-IMP/HTGR-MEU/Th & $6.5(12.8)$ & $570(914)$ & $752(1128)$ & $98(163)$ & $1420(2205)$ \\
\hline
\end{tabular}

*Numbers in parenthesis to 2050. 
TABLE 4-5

ONCE-THROUGH STRATEGIES*

HIGH DEMAND/HIGH URANIUM PRICE

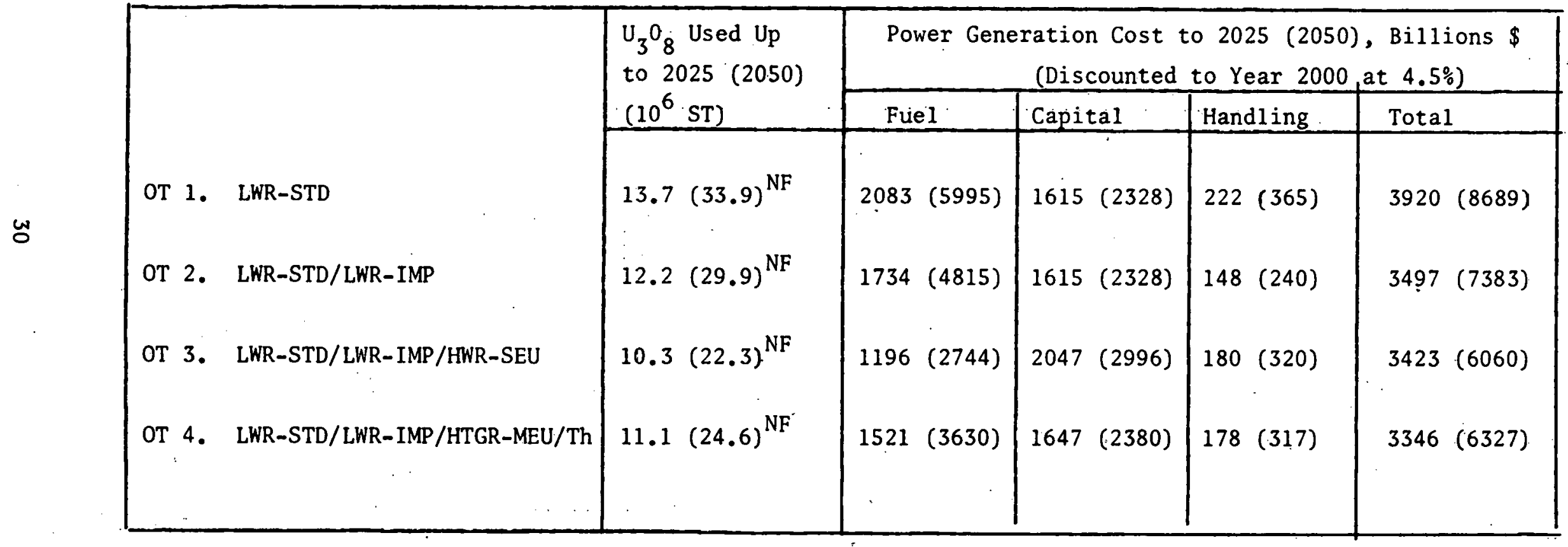

*Numbers in parenthesis to 2050

NF - Not feasible: $U>$ high speculative resources 
costs of the LWRs outweigh any fuel saving. On the other hand, with high demand and high uranium price, the HWR system's power cost is $4 \%$ less than the HTGR for the period $1975-2050$.

Overal1, the presence of the HTGR in once-through systems not only helps extend the use of available uranium but also keeps costs down. Moreover, the HTGR breeds little plutonium. Therefore, to minimize the proliferation risks and at the same time assure an adequate uranium supply, the HTGR could be a viable alternative while international arrangements are being worked out to reduce proliferation risks in fuel reprocessing. In the long-run the world cannot maintain a total once-through system and therefore other nuclear fuel cycle alternatives need to be examined.

\subsection{THERMAL RECYCLE STRATEGIES}

The $\mathrm{U}_{3} \mathrm{O}_{8}$ commitments and power costs for each thermal reactor system (with uranium and plutonium recycle) are given in Tables 4-6 and 4-7 for low demand and high demand projection, respectively.

Until 2025, there is no substantial difference among the systems in the amount of uranium required to operate the reactors. This is due to two factors: one, the system is still highly dominated by LWRs, which account for $75 \%$ of the total reactor years; and two, the higher inventory requirements of newly-installed ACRs contribute significantly to ore usage even though the annual loadings are relatively less.

From 2025 to 2050, the total ore usage for the HTGR-HEU system is only about half that of the LWR-only system.

The results also indicate that there is almost the same amount of uranium consumption for the HWR or HTGR-HEU systems. However, the higher capital cost of the HWR is its main drawback. 
TABLE 4-6

THERMAL RECYCLE STRATEGIES *

LOW DEMAND/LOW URANIUM PRICE

\begin{tabular}{|c|c|c|c|c|c|}
\hline & \multirow{2}{*}{$\begin{array}{l}\mathrm{U}_{3}{ }^{0} 8 \text { Used Up } \\
\text { to } 2025 \quad(2050) \\
\left(10^{6} \mathrm{ST}\right)\end{array}$} & \multicolumn{4}{|c|}{$\begin{array}{l}\text { Power Generation Costs to } 2025 \text { (2050) Billions } \\
\text { (Discounted to year } 2000 \text { at } 4.5 \% \text { ) }\end{array}$} \\
\hline & & Fuel & Capital & Handling & Total \\
\hline TR 1. LWR-STD & $5.8(12.0)$ & $467(766)$ & $737(1103)$ & $343(530)$ & 1547 (2399) \\
\hline TR 2. LWR-STD/HWR-SEU/HWR-MEU/Th & $5.4(8.8)$ & $447(644)$ & $930(1416)$ & 309 (447) & $1685(2507)$ \\
\hline TR 3. LWR-STD/HTGR-MEU/Th & $5.3(9.8)$ & $437(684)$ & $752(1128)$ & 294 (399) & $1483(2211)$ \\
\hline TR 4. LWR-STD/HTGR-HEU/Th & $5.2(8.4)$ & $438(630)$ & $752(1128)$ & $331(494)$ & $1523(2252)$ \\
\hline
\end{tabular}

*Numbers in parenthesis to 2050. 
TABLE 4-7

THERMAL RECYCLE STRATEGIES

HIGH DEMAND/HIGH URANIUM PRICE

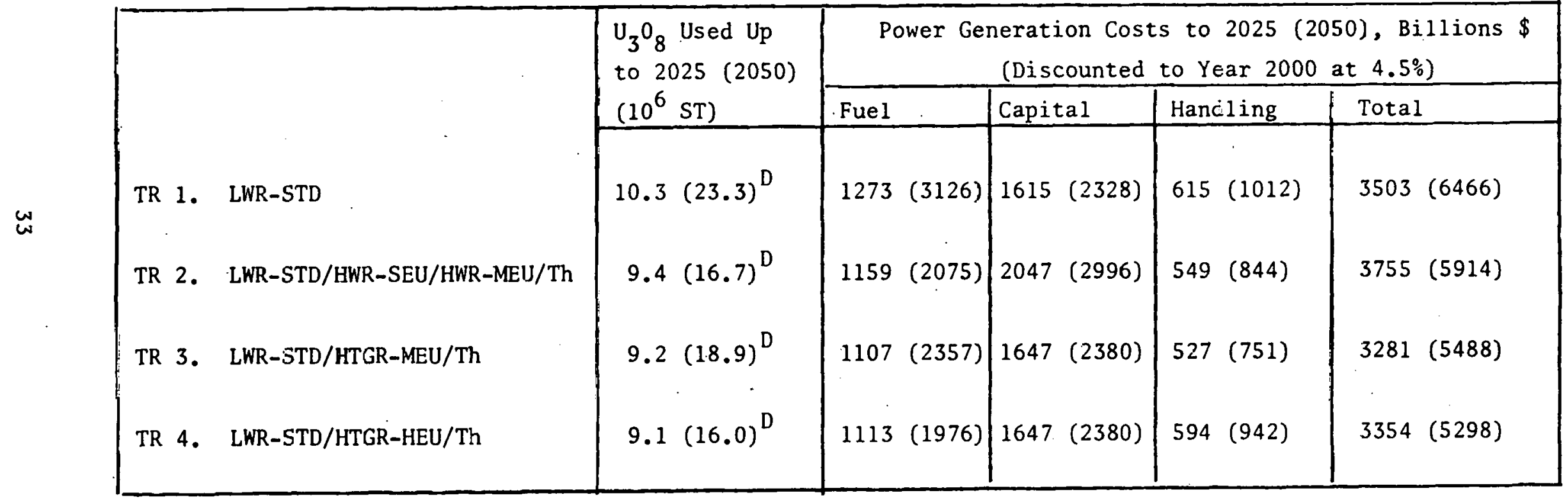

D - Doubtful: U > low speculative resources 
Up to the year 2025, the $\mathrm{U}_{3}{ }^{0} 8$ consumption for the HTGR-MEU system (TR 3) is almost the same as the HTGR-HEU system. This might appear contradictory to the fact that the HEU cycle has a higher conversion ratio, with a net $\mathrm{U}_{3} \mathrm{O}_{8}$ annual requirement of $40 \%$ less than the MEU fuel. However, to achieve this high conversion ratio, it is necessary to increase the thorium loading, which in effect increases the $\mathrm{U}_{3} \mathrm{O}_{8}$ inventory requirement. Therefore, it would take a longer period of reactor operation, certainly beyond 2025, before this inventory penalty could be overcome. Since there is virtually no saving in fuel during this time period and the heavier metal loading of the HEU fuel increases the handling cost, it is understandable that the total power cost of the MEU cycle is lower than the HEU; although the difference is not very significant.

By the year 2050, we find that the HEU cycle can save as much as 3 million short tons $\mathrm{U}_{3} \mathrm{O}_{8}$ (high demand). This saving becomes more important as the $\mathrm{U}_{3} \mathrm{O}_{8}$ price increases. Thus for the high demand/high uranium price situation, the cumulative power cost of the HTGR-HEU system for the period 1975 - 2050 is $\$ 190$ B less than the HTGR-MEU system. This suggests that in the medium term (up to 2025) the MEU cycle can be operated without economic penalty and we can later switch to the HEU cycle as resources become scarce. This would give enough time for institutional arrangements to be developed to minimize the proliferation risks associated with the use of high enriched U-233.

The results indicate that the economics of thermal recycle strategies look encouraging but the indicated benefits are very much dependent on $\mathrm{U}_{3}{ }_{8}$ price assumptions. With high uranium price, thermal recycle with HTGRs is definitely more economical than once-through strategies with improved LWRs and/or HTGRs. However, as in the case of once-through systems, self-sufficiency in ore is not possible. 


\subsection{THERMAL-FAST BREEDER REACTOR SYMBIOSIS}

Tables 4-8 and 4-9 summarize the results for the four cases evaluated (low and high demand). The results show that plutonium is best utilized in fast spectrum reactors while $U-233$ is the best fuel for thermal spectrum reactors. The breeders used in the analysis have breeding ratios of $\sim 1.4$. This is consistent with OECD's assumptions in its long-term scenario evaluations (Ref. 1). Should the breeding gain be lower, it could offset the performance of Pu-burning LWRs more than U-233 fueled advanced converters because of the more efficient utilization of U-233 in thermal reactors.

We find only very small differences in ore consumption for symbiotic systems utilizing different types of advanced converter reactors. The choice of a particular reactor type would most likely be influenced strongly by such factors as proliferation resistance, licensing and safety requirements, and economics.

Of the systems evaluated, the FBR/HTGR-HEU233 is the most resource efficient. For a high demand projection, uranium used is $55 \%$ and $77 \% 1$ ess than the standard LWR once-through in 2025 and 2050, respectively.

It is clear that the symbiotic systems utilizing U-233 not only lead to substantial ore savings, but also to lower power costs. If one is to choose between the HWR and the HTGR as U-233 consumer, economics make the HTGR a better choice. The high capital and $D_{2} 0$ costs associated with the HWR are detrimental factors.

The results also indicate that the use of high enriched U-233 is not only economically favorable but also reduces the number of breeders needed to maintain the system. Thus, Fig. 4-9 shows that the ratio of reactors outside secured areas to reactors inside secured areas is largest when high enriched U-233 is utilized in an advanced converter. 
TABLE $4-8$

THERMAL-BREEDER SYMBIOTIC STRATEGIES

LOW DEMAND/LOW URANIUM PRICE

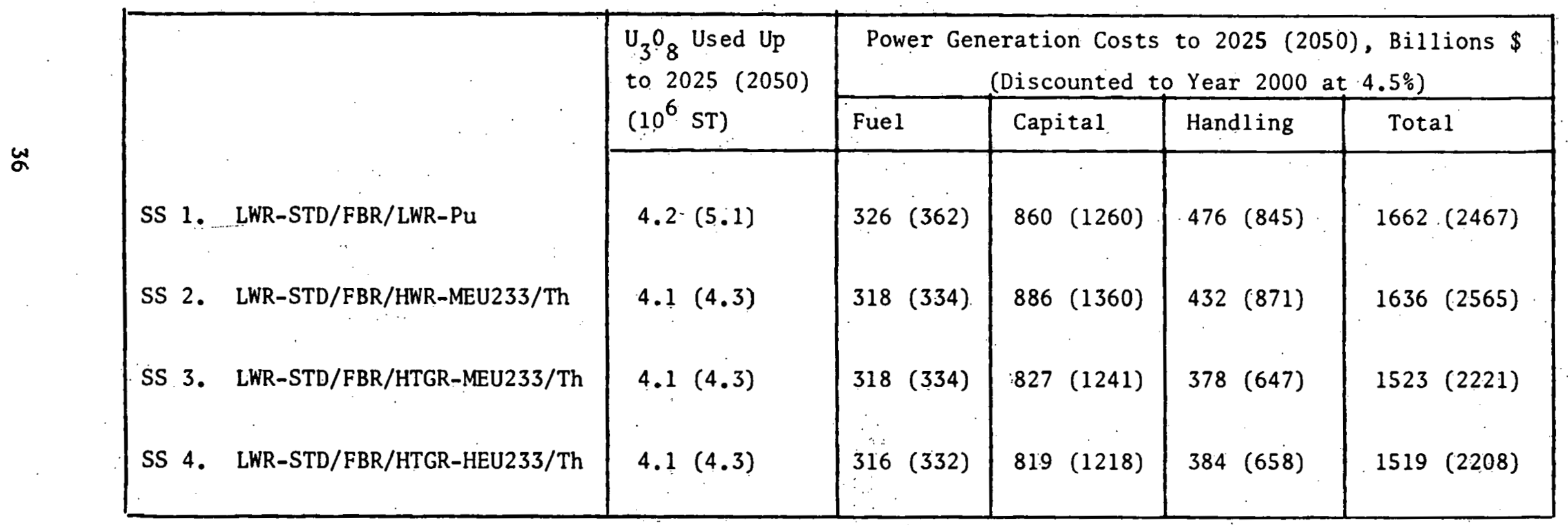


TABLE 4-9

THERMAL-BREEDER SYMBIOTIC STRATEGIES HIGH DEMAND/HIGH URANIUM PRICE

\begin{tabular}{|c|c|c|c|c|c|c|}
\hline \multirow[b]{3}{*}{ SS 1 . } & \multirow[b]{2}{*}{ 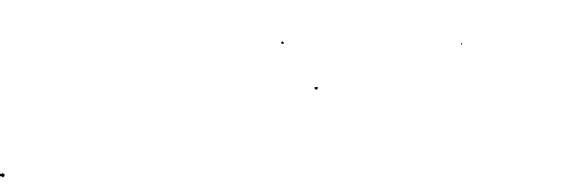 } & \multirow{2}{*}{$\begin{array}{l}\mathrm{U}_{3}{ }^{0} 8 \text { Used Up } \\
\text { to } 2025 \quad(2050) \\
\left(10^{6} \mathrm{ST}\right)\end{array}$} & \multicolumn{4}{|c|}{$\begin{array}{l}\text { Power Generation Costs to } 2025 \text { (2050), Billions \$ } \\
\text { (Discounted to Year } 2000 \text { at } 4.5 \% \text { ) }\end{array}$} \\
\hline & & & Fuel & Capital & Handling & Total \\
\hline & LWR-STD/:BR/LWR-Pu & $7.2(10.6)$ & $739(1028)$ & $1839(2614)$ & $850(1575)$ & $3428 \quad(5217)$ \\
\hline SS 2 & LWR-STD/:BR/HWR-MEU233/Th & $6.7(9.1)$ & $650(856)$ & $1916(2823)$ & $817(1663)$ & $3383(5342)$ \\
\hline SS 3 & LWR-STD/JBR/HTGR-MEU233/Th & $6.3(8.7)$ & $603(790)$ & $1789(2590)$ & $701(1242)$ & $31093(4622)$ \\
\hline SS 4 & LWR-STD/IBR/HTGR-HEU233/Th & $6.1(7.7)$ & $573(693)$ & $1781(2560)$ & $728(1291)$ & $3082(4544)$ \\
\hline
\end{tabular}


FIGURE 4-9

RATIO OF OUTSIDE TO INSIDE. SECURED AREAS VS . . TIME

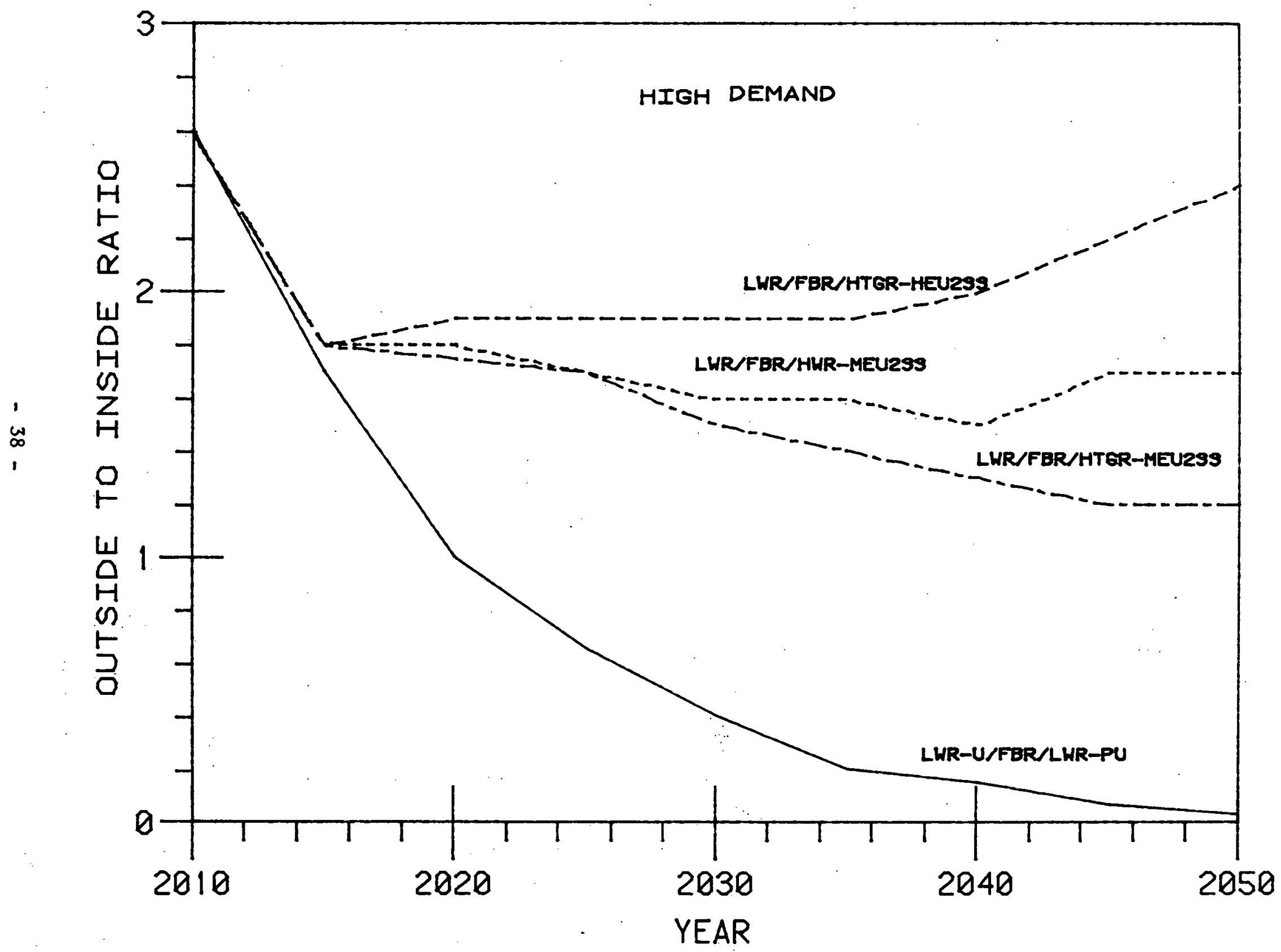


The benefits from symbiotic systems are only possible with fuel reprocessing. Serious efforts are therefore needed to solve the technological and political problems associated with reprocessing while at the same time achieving non-proliferation objectives. 


\subsection{CONCLUSIONS}

The following conclusions can be drawn from this study:

1. Uranium requirements of all systems including once-through strategies fall below the upper range of projected annual production capacity when a low nuclear growth is assumed. Should production capacity stay within the middle range $\left(\sim 170,000 \mathrm{ST} \mathrm{U}_{3}{ }_{8}\right)$, the LWR-OT strategies would not make it by 2015. For a high nuclear growth assumption, the maximum annual uranium production capacity by 2025 falls short of the annual requirements of once-through systems. Even a symbiotic system with LWRs and FBRs operating on $\mathrm{Pu}$ cycle would not make it in a high demand situation by 2025 if production capacity is in the mid-range of the projected estimate (Sec, 4.1).

2. Thermal recycle employing either an HWR or HTGR could keep uranium requirements within the range of estimated production capacity. However, with continued high growth beyond 2025, the breeders in symbiosis with U-233-consuming advanced concerters (HTGRs or HWRs) are necessary to keep uranium consumption within current estimates of available world uranium resources (Sec. 4.1).

3. For symbiotic systems, the development of uranium resources to meet demand, is largely dependent on the rate of breeder development. Rapid FBR development would delay, while slow FBR development would accelerate the speculative resource development (Sec. 4.1). 
4. The economic benefits of FBRs and ACRs are more apparent in a high demand/high uranium price scenario. This indicates that costs are highly sensitive to nuclear demand and uranium price assumptions (Figs, 4-5 \& 4-6).

5. The combination of FBRs and ACRs can serve as a hedge against uncertainties in uranium supply because the system (at equilibrium) is self-sufficient in ore; while at the same time meeting the non-proliferation objectives. Fewer breeders will be required in a system with ACRs. These breeders and their fuel cycle plants may be concentrated in special nuclear power centers under IAEA safeguards should the need arise (Sec. 4.5). .

6. The benefits from symbiotic strategies are maximized with rapid deployment of fast breeder and advanced converter reactors (Sec. 4.3)

7. Capital intensive reactors like the HWRs penalize the system in the case of a low demand or low uranium cost assumption. Development of these reactors entails higher risk (Figs. 4-5 4-8). 


\subsection{REFERENCES}

1. Nuclear Fuel Cycle Requirements, Organization for Économic Co-operation and Development (OECD), Paris, February 1978.

2. Internal memo, D. Greneche to R. H. Brogli, February 21, 1979.

3. ORNL Data Base, TM-6522, July 1978.

4. World Uranium Potential, A. Joint Report by the OECD Nuclear Energy Agency and the International Atomic Energy Agency (IAEA), Paris, December, 1978.

5. Uranium Resources, Production and Demand, A Joint Report by the OECD Nuclear Energy Agency and the International Atomic Energy Agency. (IAEA), Paris, December 1979.

\section{ACKNOWLEDGEMENTS}

The authors are extremely grateful to R. F. Turner and J. A. Larrimore for their valuable comments and suggestions and to $E$. Hettergott for providing the necessary data. 


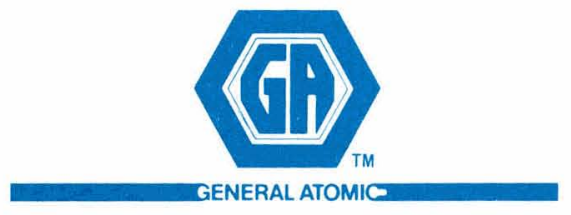

GENERAL ATOMIC COMPANY

P. O. BOX 81608

SAN DIEGO, CALIFORNIA 92138 